\title{
Balzac, I Giraviation
}

\section{Marco Stupazzoni}

\section{(2) OpenEdition}

\section{Journals}

\section{Edizione digitale}

URL: http://journals.openedition.org/studifrancesi/10667

DOI: 10.4000/studifrancesi. 10667

ISSN: 2427-5856

\section{Editore}

Rosenberg \& Sellier

\section{Edizione cartacea}

Data di pubblicazione: 1 décembre 2017

Paginazione: 563

ISSN: 0039-2944

\section{Notizia bibliografica digitale}

Marco Stupazzoni, «Balzac, I Giraviation», Studi Francesi [Online], 183 (LXI | III) | 2017, online dal 01

février 2018, consultato il 22 janvier 2021. URL: http://journals.openedition.org/studifrancesi/10667 ; DOI: https://doi.org/10.4000/studifrancesi. 10667

\section{Questo documento è stato generato automaticamente il 22 janvier 2021.}

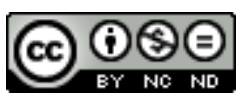

Studi Francesi è distribuita con Licenza Creative Commons Attribuzione - Non commerciale - Non opere derivate 4.0 Internazionale. 


\title{
Balzac, I Giraviation
}

\author{
Marco Stupazzoni
}

\section{NOTIZIA}

HONORÉ DE BALZAC, I Giraviation, prefazione di Edoardo Castagna, traduzione e cura di Alfredo Rovatti, con due scritti di Gérard de Nerval e Marcel Schwob, Milano, Edizioni Medusa, 2016, «Le porpore», 135 pp.

1 Pubblicato, in prima edizione, nel 1843, la Monographie de la presse parisienne di Balzac ha da sempre suscitato un meravigliato interesse nella critica contemporanea per la «smagliante attualità del testo - scrive Alfredo Rovatti nella sua Nota editoriale a p. 9 nel descrivere alcuni tipi giornalistici che si possono anche oggi ritrovare nel mondo dell'informazione». Lo scritto balzachiano è preceduto da un testo satirico e altrettanto corrosivo di G. de Nerval: La vera storia del «canard» (pp. 11-17) pubblicato nel 1845, ed è seguito da uno scritto di M. Schwob: L'isola dei Diurnali (pp. 119-134) edito nel 1903. I Giornalisti di Balzac è presente alle pp. 20-117 del volume. Secondo Edoardo Castagna, che cura la Prefazione ai tre scritti citati (pp. 5-8), è nella descrizione del contrasto tra la figura del pubblicista e quella del critico che l'opera di Balzac assume i caratteri di una rappresentazione del mondo dell'informazione applicabile ad ogni epoca e ad ogni Paese. Le figure descritte dal romanziere francese «ricorrono identiche nel nostro panorama contemporaneo» (p.5): si tratta, osserva Castagna, di un mondo che da tempo «si avvita, da una parte, nella commistione tra la critica e la propaganda; e, dall'altra, sconta l'amplificazione dei difetti della categoria giornalistica, lucidamente e impietosamente snocciolati da Balzac, dovuta alla Rete» (p. 6). 